University of Nebraska - Lincoln

DigitalCommons@University of Nebraska - Lincoln

\title{
Characterization of a Polymer Surface With Sequentially Immobilized Proteins
}

\author{
Anuradha Subramanian \\ Department of chemical Engineering,University of Nebraska Lincoln., asubramanian2@unl.edu \\ Tarlan Mammedov \\ University of Nebraska - Lincoln, tmammedov2@unl.edu \\ Karl E. Kador \\ University of Nebraska - Lincoln
}

Follow this and additional works at: https://digitalcommons.unl.edu/cbmesubramanian

Part of the Chemical Engineering Commons

Subramanian, Anuradha; Mammedov, Tarlan; and Kador, Karl E., "Characterization of a Polymer Surface With Sequentially Immobilized Proteins" (2008). Anuradha Subramanian Publications. 6.

https://digitalcommons.unl.edu/cbmesubramanian/6

This Article is brought to you for free and open access by the Chemical and Biomolecular Research Papers -- Faculty Authors Series at DigitalCommons@University of Nebraska - Lincoln. It has been accepted for inclusion in Anuradha Subramanian Publications by an authorized administrator of DigitalCommons@University of Nebraska - Lincoln. 
Published in Journal of Biotechnology 136, Supplement 1 (October 2008), p. S24; Biotechnology for the Sustainability of Human Society - IBS 2008 Abstracts, 13th International Biotechnology Symposium and Exhibition; doi 10.1016/j.jbiotec.2008.07.042

Copyright (C 2008 Published by Elsevier B.V. Used by permission.

Published online October 16, 2008.

\title{
Characterization of a polymer surface with sequentially immobilized proteins
}

\author{
Anu Subramanian, Tarlan Mammedov, and Karl E. Kador \\ University of Nebraska - Lincoln, Lincoln, Nebraska, USA \\ Corresponding author - A. Subramanian, asubramanian2@unl.edu
}

To overcome the procoagulant processes on the surfaces of biomaterials, surface modifications have been undertaken to achieve hemocompatability characteristics that are comparable to the native endothelium. Our immediate goal in this paper is to design and develop strategies to inhibit thrombin activation on biomaterial surfaces. We will use biodurable polyurethane (PU) as the background polymer and synthesize biomaterial surfaces containing two immobilized recombinant proteins. To attain our objective, we have first undertaken the surface modification of biodurable polyurethane (chronoflexAR) to enable the sequential immobilization of proteins via a bi-dentate bridge, a novel modification strategy. We have verified the creation of the bridge by surface FT-IR conducted on each intermediate and the product of the synthesis. We estimate a yield of $0.25 \mu \mathrm{mol}$ of the proposed bi-dentate bridge $/ \mathrm{cm}^{2}$ polyurethane. We have characterized the protein binding on modified PU surfaces by immunofluorescence microscopy. As expected no visible fluorescence was detected on unmodified surfaces, while PU surfaces that has immobilized proteins via the bridge gave fluorescent signals, indicating the successful immobilization as per design. Results on surface modification and characterization of the resultant surface by FT-IR and dynamic mechanical analyses and immunofluorescence microscopy will be presented. 